\title{
DETERMINANTS OF JOB PERFORMANCE AMONG NURSES AT PKU MUHAMMADIYAH HOSPITAL, YOGYAKARTA
}

\author{
Heni Rusmitasari'1), Endang Sutisna Sulaeman²), Bhisma Murti') \\ ${ }^{1)}$ Masters Program on Public Health, Universitas Sebelas Maret \\ 2)Faculty of Medicine, Universitas Sebelas Maret
}

\begin{abstract}
Background: Nurses are critical to the delivery of high-quality, efficient care. Evidences from previous studies show that hospital nurses and staff, supported by leadership, can be actively involved in improving both the quality and the efficiency of hospital care. This study aimed to examine determinants of job performance among nurses at PKU Muhammadiyah Hospital, Yogyakarta.

Subjects and Method: A cross-sectional study was conducted at PKU Muhammadiyah Hospital, Yogyakarta, from April to June 2018. A sample of 203 nurses was selected for this study by simple random sampling. The dependent variable was job performance. The independence variables were motivation, skill, tenure, and motivation. The data were collected by questionnaire and analyzed by a multiple logistic regression.

Results: Nurse job performance increased with skill $(\mathrm{OR}=5.70 ; 95 \% \mathrm{CI}=0.93$ to $3.72 ; \mathrm{p}<0.001)$, tenure $(\mathrm{OR}=2.04 ; 95 \% \mathrm{CI}=1.07$ to $3.88 ; \mathrm{p}=0.030)$, and motivation $(\mathrm{OR}=1.87 ; 95 \% \mathrm{CI}=0.93$ to $3.72 ; \mathrm{p}=0.079)$.

Conclusion: Nurse job performance increases with skill, tenure, and motivation.

Keywords: job performance, nurse, tenure, motivation, skill

\section{Correspondence:}

Heni Rusmitasari. Masters Program on Public Health, Universitas Sebelas Maret. Jl. Ir. Sutami No. 36A, Surakarta 57126, Central Java.

Email: heni.rusmitasari@gmail.com. Mobile: +6281329633782
\end{abstract}

The 4th International Conference on Public Health

Best Western Premier Hotel, Solo, Indonesia, August 29-30, 2018 | 283 https://doi.org/10.26911/theicph.2018.04.52 